\title{
Anaerobic utilization of toluene by marine alpha- and gammaproteobacteria reducing nitrate
}

\author{
Karine Alain ${ }^{1,2,3}$, Jens Harder ${ }^{4}$, Friedrich Widdel ${ }^{4}$ and Karsten Zengler ${ }^{5}{ }^{*}$
}

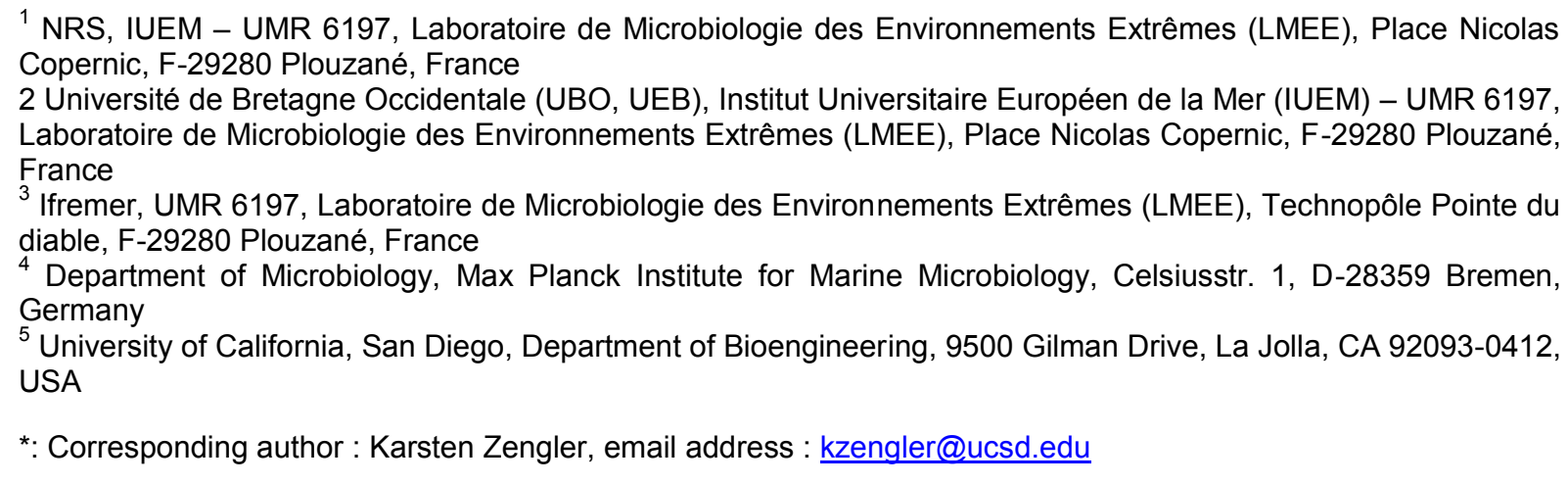

\begin{abstract}
:
Aromatic hydrocarbons are among the main constituents of crude oil and represent a major fraction of biogenic hydrocarbons. Anthropogenic influences as well as biological production lead to exposure and accumulation of these toxic chemicals in the water column and sediment of marine environments. The ability to degrade these compounds in situ has been demonstrated for oxygen- and sulphaterespiring marine micro-organisms. However, if and to what extent nitrate-reducing bacteria contribute to the degradation of hydrocarbons in the marine environment and if these organisms are similar to their well-studied freshwater counterparts has not been investigated thoroughly. Here we determine the potential of marine prokaryotes from different sediments of the Atlantic Ocean and Mediterranean Sea to couple nitrate reduction to the oxidation of aromatic hydrocarbons. Nitrate-dependent oxidation of toluene as an electron donor in anoxic enrichment cultures was elucidated by analyses of nitrate, nitrite and dinitrogen gas, accompanied by cell proliferation. The metabolically active members of the enriched communities were identified by RT-PCR of their 16S rRNA genes and subsequently quantified by fluorescence in situ hybridization. In all cases, toluene-grown communities were dominated by members of the Gammaproteobacteria, followed in some enrichments by metabolically active alphaproteobacteria as well as members of the Bacteroidetes. From these enrichments, two novel denitrifying toluene-degrading strains belonging to the Gammaproteobacteria were isolated. Two additional toluene-degrading denitrifying strains were isolated from sediments from the Black Sea and the North Sea. These isolates belonged to the Alphaproteobacteria and Gammaproteobacteria. Serial dilutions series with marine sediments indicated that up to $2.2 \times 10^{4}$ cells $\mathrm{cm}^{-3}$ were able to degrade hydrocarbons with nitrate as the electron acceptor. These results demonstrated the hitherto unrecognized capacity of alpha- and gammaproteobacteria in marine sediments to oxidize toluene using nitrate.
\end{abstract}




\section{INTRODUCTION}

32 Hydrocarbons are naturally widespread in marine sediments and can originate

33 from several natural and anthropogenic sources. Petroleum hydrocarbons

34 produced during diagenesis of organic-rich sediments and oil emitted by near-

35 surface hydrocarbon seepages constitute a natural source of hydrocarbons in

36 sediments. Some other hydrocarbons of biogenic origin are produced in living

37 organisms such as bacteria, phytoplankton, plants and metazoans (Chen et al.,

38 1998; Fischer-Romero et al., 1996; Tissot \& Welte, 1984). Furthermore, in

39 addition to hydrocarbons of biogeochemical or biogenic origin, anthropogenic

40 activities, such as off-shore production, transportation or tanker accidents,

41 municipal or industrial wastes and runoff, are responsible for additional inputs of

42 petroleum hydrocarbons into the marine environment.

44 The main constituents of petroleum hydrocarbons are branched and unbranched

45 alkanes, cycloalkanes, as well as mono- and polyaromatic hydrocarbons. Since

46 hydrocarbons can be highly toxic to a wide variety of life, the degradation of

47 these contaminants and of petroleum compounds in general is of great

48 importance. The aerobic degradation of aromatic hydrocarbons and alkanes has

49 been studied since the beginning of the $20^{\text {th }}$ century, and numerous aerobic

50 hydrocarbon-degrading microorganisms have been isolated (e.g., Austin et al.,

51 1977; Gibson \& Subramanian, 1984; Teramoto et al., 2009). Even though

52 hydrocarbons are among the least chemically reactive molecules, microbial-

53 mediated degradation has also been demonstrated under anoxic conditions and 
54 several anaerobic phototrophic, nitrate-, iron-, sulphate-reducing, and fermenting

55 bacteria have been isolated or enriched over the last decades (Heider et al., 56 1999; Widdel et al., 2010). The activity of sulphate-reducing bacteria in oil

57 reservoirs and in on- and offshore oil operation has been of great interest from an

58 industrial perspective, since detrimental souring (production of sulphide) has

59 been associated with this group of bacteria. One of the strategies to control

60 souring has been the addition of nitrate to oil reservoirs and surface facilities,

61 which can have a direct impact on the sulphate-reducing population (Gieg et al.,

62 2011). The anaerobic degradation of aromatic hydrocarbons and alkanes with

63 nitrate as terminal electron acceptor has been previously demonstrated and

64 extensively studied in freshwater environments. Almost all the nitrate-reducing

65 strains isolated so far from terrestrial and freshwater environments belong to the

66 Betaproteobacteria, and more especially to the genera Thauera, Azoarcus and

67 Georgfuchsia (Dolfing et al., 1990; Evans et al., 1991; Fries et al., 1994; Hess et

68 al., 1997; Rabus \& Widdel, 1995b; Ehrenreich et al., 2000; Weelink et al., 2009).

69 Two of the few exceptions so far are hydrocarbon-degrading denitrifiers

70 belonging to the Gammaproteobacteria that have been isolated from river

71 sediment (genus Dechloromonas) (Chakraborty et al., 2005) and ditch sediment

72 (strain HdN1) (Ehrenreich et al., 2000; Zedelius et al., 2011). Betaproteobacteria

73 that dominate the oxidation of hydrocarbons in freshwater environments,

74 however, are commonly not dominant in marine sediments. Furthermore, nitrate-

75 reducing microorganisms of marine origin capable of hydrocarbon degradation

76 have so far not been validly described. To date, fully characterized anaerobic 
77 hydrocarbon-degrading strains from marine sediments are all iron-, or sulphate-

78 reducing bacteria.

79 The aim of this study was to elucidate nitrate-dependent degradation of

80 hydrocarbons in various marine sediments and to determine the identity of

81 potential microorganisms involved in the process The alkyl-substituted

82 monoaromatic hydrocarbon toluene was chosen as model substrate since it is a

83 widespread hydrocarbon that has been intensely studied. Additional experiments

84 were also performed with the short-chain aliphatic alkane $n$-hexane. The findings

85 have implications on our understanding of the role of these organisms in

86 hydrocarbon degradation in marine settings and on practices by the oil industry

87 to reduce souring by addition of nitrate.

89 METHODS

90 Sources of organisms, media and cultivation procedures. Enrichment

91 cultures and enumeration of viable nitrate-reducers were performed from marine

92 sediments collected from five different sites. Two samples were coastal

93 sediments from La Manche (France), an epicontinental Sea of the Atlantic, and

94 were collected respectively from a subtidal station from Térénez beach $(=T B)$ in

95 Plougasnou (France) and from the harbor of Le Dourduff en Mer (=LD) in

96 Plouézoc'h (France). A third sample was collected from a polyhaline (17\%

97 salinity) Mediterranean lagoon (=ML) located near the Etang de Berre (France).

98 This sediment was collected in a station where deposits of petroleum residues

99 were covered by saltwater. In addition, two samples were used to perform 
100 enrichment cultures and isolations with toluene, as well as counting series. The

101 first one was collected in the North Sea (=NS), in a small harbor (Horumersiel)

102 located near Wilhemshaven (Germany). The second one originated from a 103 sampling station of the Black Sea (=BS) located off the Romanian coast.

104 Sediments cores were collected with polyacryl tubes and stored under nitrogen.

105 The upper four $\mathrm{cm}$ of the sediment cores were used for this work.

107 Procedures for preparation of media and for cultivation under anoxic conditions 108 were as described elsewhere (Widdel \& Bak, 1992). Cultures were incubated at $10920^{\circ} \mathrm{C}$ in $\mathrm{HCO}_{3}{ }^{-} / \mathrm{CO}_{2}{ }^{-}$-buffered full marine mineral medium, supplemented with 110 vitamins and trace elements as described (Widdel et al., 2004) with minor 111 modifications to accommodate the needs of denitrifiers: $100 \mathrm{mg} / \mathrm{l} \mathrm{MnCl}_{2} \cdot 4 \mathrm{H}_{2} \mathrm{O}$ 112 and $29 \mathrm{mg} / \mathrm{l} \mathrm{CuCl} 2 \cdot 2 \mathrm{H}_{2} \mathrm{O}$. Nitrate was used at a final concentration of $5 \mathrm{mM}$, and 113 resupplied after consumption. Anoxic conditions in enrichments were achieved 114 solely by degassing and flushing with $\mathrm{N}_{2} / \mathrm{CO}_{2}(90 / 10, \mathrm{v} / \mathrm{v})$. In pure cultures, 0.5 $115 \mathrm{mM}$ of sodium sulfide or $4 \mathrm{mM}$ of freshly prepared sodium ascorbate were used 116 in addition to establish reducing conditions (Widdel et al., 2004). Ascorbate did 117 not serve as a growth substrate for the isolated strains. Toluene and $n$-hexane 118 were prepared as described elsewhere (Ehrenreich et al., 2000; Widdel et al., 119 2004), and resupplied when consumed. Enrichment cultures were performed in 120 butyl-rubber-stopper-sealed $250 \mathrm{ml}$ flat glass bottles containing $8 \mathrm{ml}$ of 121 homogenized sediments, $150 \mathrm{ml}$ of mineral medium, and $16 \mathrm{ml}$ of the substrate122 containing carrier phase, under a headspace of $\mathrm{N}_{2} / \mathrm{CO}_{2}(90 / 10, \mathrm{v} / \mathrm{v})$. Subcultures 
123 contained $150 \mathrm{ml}$ medium, $20 \mathrm{ml}$ of the initial enrichment, $19 \mathrm{ml}$

124 heptamethylnonane (HMN) and $190 \mu \mathrm{l}$ of the aromatic or aliphatic hydrocarbon.

125 All the enrichment cultures were performed in duplicates in addition to one 126 control without substrate.

128 The most probable-number (MPN) method was used in five replicates series with

129 10-fold dilutions in liquid medium, and calculations were done using standard

130 tables. MPN were performed with the following substrates: acetate $(20 \mathrm{mM})$,

131 benzoate $(4 \mathrm{mM}), n$-hexane $(1 \% \mathrm{v} / \mathrm{v}$ in $\mathrm{HMN})$ and toluene $(1 \% \mathrm{v} / \mathrm{v}$ in $\mathrm{HMN})$. This

132 experiment was incubated over a period of 90 days at $20^{\circ} \mathrm{C}$ in the dark. In MPN

133 series and to test the ability of the isolates to grow on different substrates, water-

134 soluble substrates were added from concentrated, separately sterilized stock

135 solutions in water to yield the indicated concentrations, and short-chain alkanes

$136\left(<\mathrm{C}_{12}\right)$ and aromatic hydrocarbons were diluted in HMN. Growth experiments

137 with aromatic hydrocarbons in the presence of oxygen were carried out as

138 described elsewhere (Rabus \& Widdel, 1995b). All used chemicals were of 139 analytical grade.

141 Growth indicators, analytical procedures and chemical analyses. In the 142 initial enrichment cultures, growth was monitored by quantifying the gas 143 production in a gas-tight syringe, and determining the nitrogen content of the gas 144 by trapping of the carbon dioxide, as described previously in detail (Rabus et al., 145 1999). In addition, more accurate measurements of nitrate and nitrite contents 
146 were performed by high-performance liquid chromatography (HPLC), as detailed

147 below.

149 The initial enrichment cultures were further transferred (inoculum size: $25 \%$ ) in 150 fresh media and incubated under the same conditions. In these subcultures, the

151 time course of growth and activity were monitored with precision at the 152 microbiological (cell counts) and chemical (reactants and products of the 153 metabolism) level. Cells were observed under a light microscope (Zeiss; x100 154 magnification) and enumerated using a Neubauer chamber (depth $0.02 \mathrm{~mm}$ ).

155 Nitrate and nitrite were measured by HPLC on an IBJ A3 High Speed NOx anion 156 exchange column $(4 \times 60 \mathrm{~mm})$ (Sykam, Germany), connected to an HT300 157 autosampler (WICOM; GAT GmbH Bremerhaven, Germany). The eluent was 20 $158 \mathrm{mM} \mathrm{NaCl}$ in aqueous ethanol $(45 \% \mathrm{v} / \mathrm{v})$. The flow rate was $1 \mathrm{ml} / \mathrm{min}$ and the 159 temperature of the column was constant at $50^{\circ} \mathrm{C}$. Nitrate (retention time: $3.3 \mathrm{~min}$ ) 160 and nitrite (retention timer: $2.3 \mathrm{~min}$ ) were detected at $220 \mathrm{~nm}$ with an UV 161 detector. Data acquisition and processing were performed with the Clarity 162 software (DataApex, Czech Republic). Ammonium was measured using the 163 indophenol formation reaction (Marr et al., 1988).

164 Concentrations of toluene and $n$-hexane in samples from the carrier phase were 165 determined by gas chromatography as described before (Rabus \& Widdel, 166 1995a; Zengler et al., 1999). 
168 Total RNA extraction. Total RNA was extracted from the $50 \mathrm{ml}$ enrichment 169 cultures (after one transfer) by using a modification of a protocol described 170 previously (Oelmüller et al., 1990). After centrifugation, pelleted cells were 171 resuspended in STE buffer $(10 \mathrm{mM}$ Tris-HCl pH 8.3, $1 \mathrm{mM}$ EDTA pH 8.0, 100 $172 \mathrm{mM} \mathrm{NaCl} \mathrm{pH} \mathrm{8.0)} \mathrm{and} \mathrm{ribonucleic} \mathrm{acids} \mathrm{were} \mathrm{extracted} \mathrm{by} \mathrm{successive} \mathrm{additions}$

173 of hot acidic phenol (Roti®-Aqua-Phenol, pH 4.5-5.0; Roth $\mathrm{GmbH}$, Karlsruhe, 174 Germany) prewarmed at $60{ }^{\circ} \mathrm{C}$ and SDS (sodium dodecyl sulphate) $10 \%(\mathrm{w} / \mathrm{v})$.

175 After addition of $3 \mathrm{M}$ sodium acetate solution, aqueous phases were extracted 176 with one volume of hot phenol. Then, aqueous phases were collected and 177 extracted with equal volumes of buffered ( $\mathrm{pH}$ 4.5-5.0) phenol-chloroform-isoamyl 178 alcohol (Rotiß-Aqua-PCl 25:24:1; Roth $\mathrm{GmbH}$, Karlsruhe, Germany), and finally 179 with one volume of $100 \%$ chloroform. Nucleic acids in the aqueous phases were 180 subsequently precipitated by addition of cold isopropanol, washed with $70 \%$ 181 ethanol, dried and resuspended in RNAse-free deionized water. An aliquot of the 182 suspended nucleic acids was digested with RNase-free DNasel (1 $\mathrm{U} / \mu \mathrm{l}$, 183 Promega, Mannheim, Germany), in a mixture containing DNase 10xbuffer 184 (Promega, Mannheim, Germany), dithiothreitol (DTT $0.1 \mathrm{~mol} / \mathrm{l}$, Roche) and

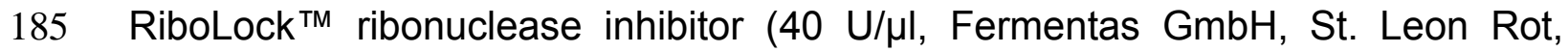
186 Germany), according to the manufacturer instructions. The reaction was stopped 187 by the addition of stop-solution (ethylene glycol tetraacetic acid (EGTA), $\mathrm{pH}$ 8.0, $18820 \mathrm{mM}$; Promega, Mannheim, Germany). The removal of DNA was confirmed by 189 PCR with universal primers. RNA aliquots were further purified with RNeasy Mini 190 purification columns (Qiagen, Hilden, Germany). Deionized water used to 
191 prepare buffers and solutions for RNA extraction was treated $(0.1 \%)$ with

192 diethylpyrocarbonate (DEPC), then autoclaved for $20 \mathrm{~min}$ at $121{ }^{\circ} \mathrm{C}$. Plastic

193 wares used for the RNA extraction and storage were RNase-free.

195 RT-PCR amplification of 16S rRNA and cloning. About $2 \mu \mathrm{g}$ of RNA were

196 reverse transcribed using the RevertAid ${ }^{\mathrm{TM}} \mathrm{H}$ Minus M-MuLV reverse

197 transcriptase (Fermentas $\mathrm{GmbH}$, St. Leon Rot, Germany) and $20 \mathrm{pmol}$ of the

198 primer GM4r (Muyzer et al., 1995), following the manufacturer's instructions.

199 After completion of the RT reactions, PCR amplifications were performed with the

200 universal 16S rDNA bacterial primers GM4r and GM3f (Muyzer et al., 1995). 16S

201 rRNA gene libraries were constructed by pooling products of two parallel RT-

202 PCR amplifications from the duplicate enrichments. Then the combined PCR

203 products were cloned directly using the TOPO TA Cloning ${ }^{\circledR}$ kit $\left(\mathrm{pCR}^{\circledR} 4-\mathrm{TOPO}^{\circledR}\right.$

204 suicide vector) and E. coli TOP10F competent cells, according to the

205 manufacturer's specifications (Lifetechnology, Carlsbad, CA, USA). To reduce

206 cloning biases, clones of two parallel cloning experiments were combined to

207 construct each library. Plasmid DNA from each clone was extracted using the

208 Montage $^{\mathrm{TM}}$ Plasmid Miniprep ${ }_{96}$ Kit (Millipore, Schwalbach, Germany), according

209 to the manufacturer's recommendations. Plasmids were checked for the

210 presence of inserts on agarose gels, and then plasmids containing correct-size

211 inserts were used as template for sequencing. Inserts were sequenced by Taq

212 cycle on an ABI 3130XL sequencer (Applied Biosystems, Foster City, CA, USA), 
213 using the following primers: GM3f (Muyzer et al., 1995), 520f (5'-GCG CCA GCA

214 GCC GCG GTA A-3') and GM4r (Muyzer et al., 1995).

216 Phylogenetic analyses. Insert-containing clones were partially sequenced and

217 fragments were analysed using the DNASTAR Lasergene 6 package (Madison,

218 WI, USA). These partial sequences were aligned in Megalign using the Clustal W

219 program, and adjusted to the same size. Sequences displaying more than $97 \%$

220 similarity were considered to be related and grouped in the same phylotype. At

221 least one representative of each unique phylotype was completely sequenced.

222 Sequences were assembled with the SeqMan program (DNASTAR Lasergene 6

223 software, Madison, WI, USA). Sequences were checked for chimera formation by

224 comparing phylogenetic tree topologies constructed from partial sequences. To

225 identify putative close phylogenetic relatives, sequences were compared to those

226 in available databases by use of BLAST (Altschul et al., 1990). Then, sequences

227 were aligned to their nearest neighbours using the SeaView4 program with the

228 Muscle Multiple Alignment option (Gouy et al., 2010). Alignments were refined

229 manually and trees were constructed by the PHYLIP (PHYlogeny Inference

230 Package) version 3.69 software (http://evolution.genetics.

231 washington.edu/phylip/getme.html) on the basis of evolutionary distance (Saitou

$232 \&$ Nei, 1987) and maximum likelihood (Felsenstein, 1981). The robustness of

233 inferred topologies was tested by using 100 to 1000 bootstrap resampling

234 (Felsenstein, 1985). Phylogenetic trees were generated using the SEQBOOT,

235 DNAPARS, DNAML and DNADIST then Neighbour-Joining. Rarefaction curves 
236 were calculated with the freeware program aRarefactWin

237 (http://www.uga.edu/strata/software/Software), with confidence intervals of 95\%.

239 Nucleotide sequence accession numbers. The clone sequence data reported

240 in this article appear in the EMBL, GenBank and DDBJ sequence databases

241 under the accession numbers AM292385 to AM292411. The nucleotide

242 accession numbers of the isolates are AM292412, AM292414, AJ133761 and

243 AJ133762.

245 Cell fixation and fluorescent in situ hybridization (FISH). Culture subsamples

246 (from the initial enrichment cultures and subcultures) were fixed at room

247 temperature for 2 to $4 \mathrm{~h}$ with formaldehyde (3\% final concentration), washed

248 twice with phosphate-buffered saline solution (PBS; $10 \mathrm{mM}$ sodium phosphate

$249 \mathrm{pH} 7.2,130 \mathrm{mM} \mathrm{NaCl})$, and then stored in PBS:ethanol (1:1) until analysis. FISH

250 was performed on polycarbonate filters (GTTP filters, pores: $0.2 \mu \mathrm{m}$; Millipore) as

251 previously described (Snaidr et al., 1997; Fuchs et al., 2000). The following

252 oligonucleotide probes were used: EUB338 (specific for most groups of the

253 domain Bacteria); ALF968 (specific for the Alphaproteobacteria, with the

254 exception of Rickettsiales); BET42a (specific for the Betaproteobacteria);

255 GAM42a (specific for most Gammaproteobacteria); CF319a (specific for some

256 groups of the Cytophaga-Flavobacterium group of the Bacteroidetes); ARCH915

257 (specific for Archaea) (Amann et al., 1990; Manz et al., 1992; Manz et al., 1996;

258 Neef, 1997). The labeled GAM42a and BET42a probes were used, respectively, 
259 with the unlabeled competitors BET42a and Gam42a. Hybridization with probe

260 NON338 (control probe complementary to EUB338; (Wallner et al., 1993)) was

261 performed as a negative control. For each probe and sample, 200-700 cells

262 counterstained with DAPI (4,6-diamidino-2-phenylindole) were counted using an

263 epifluorescence Zeiss microscope. All probes were labelled with Cy3

264 (indocarbocyanine)-dye at the 5' end and purchased from ThermoHybaid (Ulm,

265 Germany).

266

267 Isolation, purity control, and maintenance of strains. Toluene-degrading

268 denitrifiers were isolated from enrichment cultures via repeated agar dilution

269 series (Widdel \& Bak, 1992) overlaid with the hydrocarbon diluted in HMN, then

270 followed by dilutions to extinction in liquid medium. Purity of the isolates was

271 confirmed by microscopic observations (notably after addition of $0.5 \mathrm{~g} / \mathrm{l}$ yeast

272 extract or $5 \mathrm{mM}$ glucose) and sequencing. For maintenance, strains were grown

273 on the same hydrocarbon as used for the enrichment, stored at $4{ }^{\circ} \mathrm{C}$ and

274 transferred every 3 weeks.

275

276 DNA G+C content. The $G+C$ content was determined by the Identification

277 Service of the DSMZ (Deutsche Sammlung von Mikroorganismen und

278 Zellkulturen Gmb, Braunschweig, Germany) (Mesbah et al., 1989).

280 RESULTS

281 Enrichment of toluene- or $\boldsymbol{n}$-hexane utilizing denitrifying bacteria 
282 Anaerobic nitrate-dependent degradation of hydrocarbons in marine sediments

283 was investigated by enrichment cultures performed with three marine sediments

284 (TB, LD, ML, see Methods). The alkyl-substituted monoaromatic hydrocarbon

285 toluene and the short-chain aliphatic alkane $n$-hexane were chosen as model

286 substrates since they have been most intensely studied among their class.

287 Enrichment for anaerobic prokaryotes oxidizing hydrocarbons with nitrate (5 mM)

288 as electron acceptor was performed at $20^{\circ} \mathrm{C}$ in artificial seawater, with toluene or

$289 n$-hexane as sole organic substrate (each $1 \% \mathrm{v} / \mathrm{v}$ in carrier phase). Upon

290 depletion of nitrate and nitrite during the first 12 to 18 days of incubation, nitrate

291 was resupplied in increments of $5 \mathrm{mM}$. After $2 \frac{1}{2}$ weeks and consumption of 2.5

$292 \mathrm{mM}$ (for TB and LD sediments) and $12 \mathrm{mM}$ (for $\mathrm{ML}$ sediment) nitrate, gas

293 production ceased in control cultures, indicating that the endogenous organic

294 compounds from the sediments usable by the indigenous denitrifiers were

295 depleted. From here on, gas production in the enrichment cultures containing

296 hydrocarbons increased gradually, indicating enrichment of $n$-hexane or toluene-

297 utilizing microbes, reducing nitrate. After incubating the cultures for six weeks,

29815.5 to $22.7 \mathrm{mM}$ nitrate was consumed in the cultures on toluene and 16.8 to

$29917.3 \mathrm{mM}$ in the cultures on $n$-hexane, representing, respectively, a theoretical

300 consumption of $19-28 \%$ and $24-25 \%$ of the added hydrocarbons. Subsequently,

301 these cultures were transferred into new media. These positive subcultures were

302 incubated and surveyed over a period of 29 days. Growth in these enrichment

303 cultures was monitored by cell-counts and determination of nitrate reduction by

304 HPLC. Additionally, production of gas in these cultures was measured (Fig. 1). 
305 All enrichment cultures showed intermediate nitrite accumulation. Formation of

306 ammonium was not detected, indicating that ammonification did not play a

307 significant role in these enrichments. After 29 days incubation, between 25 and

$30830 \mathrm{mM}$ nitrate was consumed in the cultures on toluene and between 10 and 12

$309 \mathrm{mM}$ in the cultures on $n$-hexane. This corresponded to a theoretical oxidation of

$310 \sim 33-40 \%$ of the toluene and $\sim 15-18 \%$ of the $n$-hexane via denitrification, based

311 on an assumption of complete oxidation of the hydrocarbons. In fact, GC

312 measurements revealed nearly complete disappearance of toluene at this point.

313 Besides a small physical loss (potential absorption in the stopper), the

314 hydrocarbons were utilized for denitrification and biomass formation. It had been

315 shown previously for the pure culture of strain HdN1, that less than $60 \%$ of

316 electrons derived from complete oxidation of the alkane were consumed by

317 nitrate reduction (Ehrenreich et al., 2000). Incomplete oxidation of the

318 hydrocarbon and formation of intermediates could theoretically also contribute to

319 the discrepancy, although such has not yet been observed in denitrifying pure

320 cultures. For the cultures on $n$-hexane, data are not as comprehensive as data

321 on toluene, since $n$-hexane concentration was not monitored. Nevertheless, as

322 nitrate depletion was observed in these cultures and as nitrate consumption was

323 closed to zero in the controls without $n$-hexane, $n$-hexane is likely to sustain

324 microbial growth. At the end of the incubation period, similar cell types were

325 observed in duplicate enrichment cultures on toluene or on $n$-hexane. In all

326 cases, cultures were dominated by short rod-shaped morphotypes, normal-size

327 bacilli, as well as coccoid cells. Numerous cells were in division. Cell numbers 
328 increased four to eight folds during that incubation and reached $1 \times 10^{7}$ cells $/ \mathrm{ml}$

329 (for $n$-hexane) to $6 \times 10^{7}-6 \times 10^{8}$ cells $/ \mathrm{ml}$ (for toluene).

331 Phylogenetic affiliations of active bacteria from enrichment cultures, and 332 respective abundances

333 Active prokaryotes within the enrichment cultures were identified by extracting

334 total RNA followed by analysis of the 16S rRNA genes obtained through RT-PCR

335 amplification. No PCR products were obtained from controls in which reverse

336 transcriptase was omitted, confirming the absence of contaminating DNA during

337 RNA preparation. In all cases, nearly full length 16S rRNA genes could be

338 amplified from crDNA with universal bacterial primers. A total of 48 to 53 insert-

339 containing crDNA clones were randomly selected from clone libraries and a

340 partial sequence of $\sim 500 \mathrm{bp}$ was obtained for each clone. Sequences differing

341 less than $3 \%$ were considered as a single relatedness group based (Rosselló-

342 Mora \& Amann, 2001) and grouped as a single phylotype. One representative for

343 each phylotype was sequenced in full. Rarefaction curves were calculated from

344 the clone library phylotypes. All calculated rarefaction curves reached the

345 saturation limit, assuring that the vast majority of bacterial diversity in the

346 enrichment cultures was detected. The relative proportion of each taxonomic

347 group was determined by fluorescent in situ hybridization, carried out with group-

348 specific rRNA-targeted oligonucleotide probes (Table 1). Phylogenetic analyses

349 of the rRNA gene sequences revealed that the bacterial community in marine

350 sediments enriched on toluene or $n$-hexane consisted of several phylotypes 
351 affiliated to the Gammaproteobacteria (Fig. 2). Although the percentage of

352 Gammaproteobacteria in these different enrichments varied (Table 1), based on

353 whole-cell hybridization they represented (for the most part) the main phylotypes.

355 Toluene-grown cultures from Térénez beach

356 Whole-cell hybridization applied to toluene-grown cultures from TB sediment

357 revealed that more than $80 \%$ of the cells detectable by DAPI-staining yielded a

358 hybridization signal with probe GAM42a, specific for most groups of

359 Gammaproteobacteria (Table 1). All the detected phylotypes were only distantly

360 related (<93\% 16 S rDNA similarity) to known bacterial genera with cultivated

361 representatives, indicating that so far unkown species were involved in nitrate-

362 dependent degradation of toluene at this site.

363

364 Toluene-grown cultures from a Mediterranean lagoon

365 The toluene-grown enrichment cultures from ML sediment, resulted in sequences

366 belonging to the Gammaproteobacteria and Bacteroidetes (Fig. 2 and 3). In

367 these cultures, only $82 \%$ of the cells hybridized with probe EUB338 specific for

368 the bacterial domain. This quite low hybridization signal might be explained by

369 the fact that some cells reached already the stationary growth phase due to

370 substrate depletion and therefore exhibited a decreased cellular rRNA content

371 (Fukui et al., 1996). Only $18 \%$ of the DAPI-stained cells yielded a hybridization

372 signal with probe CF319a. This probe was specific for only two phylotypes of

373 Bacteroidetes among the four phylotypes detected in clone library. Only $13 \%$ of 
374 the cells hybridized with probe GAM42a. Most of the sequences of Bacteroidetes

375 from the toluene-grown enrichment cultures clustered in three neighboring

376 phylotypes affiliated with the family Flavobacteriaceae. Sequences of

377 Gammaproteobacteria were all related to the genus Marinobacter.

379 n-hexane-grown cultures from a Mediterranean lagoon

380 Similar to the toluene enrichment, the bacterial community enriched on $n$-hexane

381 from the ML sediments was also composed of Gammaproteobacteria and

382 Bacteroidetes (Fig. 2 and 3). In that case again, Gammaproteobacteria were

383 quantitatively dominant in the enrichment cultures, as demonstrated by

384 hybridization with probe GAM42a (Table 1). The clone library comprised

385 sequences for Marinobacter spp., distantly related to cultivated members, and

386 sequences affiliated with the genus Halomonas. Halomonas species can grow

387 anaerobically using either nitrate or nitrite, on a wide range of organic substrates

388 (Martinez-Canovas et al., 2004).

390 Toluene-grown cultures from Le Dourduff en Mer

391 Hybridization of toluene cultures from LD sediment also indicated dominance of

392 Gammaproteobacteria (Table1). Two phylotypes affiliated with this subclass did

393 not have any close cultivated representative. However, several sequences from

394 the library of this site were related to the genus Thauera $(97-98 \% 16 \mathrm{~S}$ rRNA

395 similarity with sequences of Thauera species) of the Betaproteobacteria. Whole-

396 cell hybridization confirmed that a significant fraction (36\%) of the enriched cells 
397 belonged to the Betaproteobacteria. Members of the genus Thauera are known

398 as efficient alkane or aromatic hydrocarbon degrading denitrifiers and are

399 widespread in freshwater environments. However, Betaproteobacteria are rarely

400 retrieved in marine habitats and their presence at this site is likely due to the

401 location of the collection site near a river mouth. It might therefore be assumed

402 that these Betaproteobacteria have a freshwater origin. The remaining 403 sequences were related to the Bacteroidetes and represented only a minor

404 fraction of the enriched prokaryotes, as indicated by hybridization with probe 405 CF319a.

407 n-hexane-grown cultures from Le Dourduff en Mer

408 The denitrifying community grown on $n$-hexane from the same LD sediment 409 comprised mainly of Bacteroidetes, Gamma- and Alphaproteobacteria (Fig. 2 and

4103 3). The majority of cells grown with $n$-hexane also hybridized with probe GAM42a

411 (Table 1). Sequences belonging to the Gammaproteobacteria were diverse and 412 clustered in four phylotypes. Most sequences were affiliated with phylotypes

413 belonging to the genus Marinobacter (96 to $99 \% 16 \mathrm{~S}$ rDNA similarity with

414 sequences of Marinobacter species). Marinobacter species are Gram-negative,

415 halophilic bacteria able to grow heterotrophically on a wide range of substrates 416 with oxygen or nitrate as terminal electron acceptor (Gauthier et al., 1992; Huu et

417 al., 1999). Although it has previously been demonstrated that Marinobacter

418 species are able to utilize alkanes, their capability to do so anaerobically with

419 nitrate as a terminal electron acceptor has to our knowledge never been 
420 investigated. Other Gammaproteobacteria sequences from this enrichment were

421 related to environmental clone sequences from polluted habitats. Bacteroidetes

422 represented a significant fraction of the DAPI-stained cells as demonstrated by

423 FISH counts with probe CF319a (Table 1). Two phylotypes with no close

424 cultivated relatives were found to belong to the Alphaproteobacteria. A total of

$4255 \%$ of cells in the enrichment culture yielded a hybridization signal with probe

426 ALF968 that covers the Alphaproteobacteria.

428 In addition, FISH analysis demonstrated that the bacterial community enriched

429 on toluene from NS sediment was strongly dominated by Gammaproteobacteria,

430 while the enrichment from BS sediment was dominated by Alphaproteobacteria

431 (Table 1).

432

434 Isolation of marine toluene-degrading denitrifiers

435 The presence of taxa for which members' alkylbenzene utilization has not been

436 demonstrated prompted isolation of denitrifying toluene-oxidizers from the

437 enrichment cultures with toluene by repeated agar dilutions series. New toluene-

438 utilizing denitrifying strains were isolated and one representative strain of each

439 taxon was described in more detail.

441 Strain DT-T was isolated from the enrichment culture performed with LD 442 sediment. Cells were motile and coccoid-shaped (Fig. 4a). The strain grew under 
443 anaerobic conditions on toluene, m-xylene, and diverse organic acids, using

444 nitrate as a terminal electron acceptor (Table 2). Phylogenetic analyses of the

445 16S rRNA gene revealed that this strain belonged to the genus Halomonas within

446 the Gammaproteobacteria (Fig. 2). Members of the genus Halomonas are

447 composed of mostly marine and moderately halophilic prokaryotes with

448 phenotypically very diverse capabilities (Sanchez-Porro et al., 2010; Ventosa et

449 al., 1998). Most Halomonas species are aerobes, but can also grow

450 anaerobically using either nitrate or nitrite as electron acceptor. Some

451 Halomonas species have been described to degrade benzoate or phenol under

452 aerobic conditions (Alva \& Peyton, 2003). However, the ability of this validly

453 described species to grow anaerobically on aromatic compounds has not been

454 described.

456 Cells from strain TT-Z, isolated from TB sediments, were rod-shaped and motile

457 (Fig. 4b). Strain TT-Z grew organotrophically on toluene, $m$-xylene, and on 458 variety of organic acids, using nitrate as a terminal electron acceptor (Table 2).

459 Analysis of the 16S rRNA gene revealed that strain TT-Z was affiliated with the

460 genus Sedimenticola among the Gammaproteobacteria. It was closely related to

461 the species Sedimenticola selenatireducens (96\% 16S rDNA similarity), a strain

462 able to grow anaerobically on 4-hydroxybenzoate coupled to selenate reduction

463 (Narasingarao \& Haggblom, 2006).

464 
465 Two additional toluene-utilizing denitrifiers were isolated from enrichment 466 cultures and repeated agar dilutions series using sediments from the North Sea

467 (NS) and the Black Sea (BS) as inoculum source. Strain Col2, isolated from

468 North Sea sediment, consisted of oval-shaped to spherical cells (Fig. 4c) that

469 were non-motile and tended to form loose aggregates in liquid culture. This

470 isolate utilized toluene and a wide range of substrates via denitrification (Table

471 2). Similar to strain DT-T, this strain was affiliated to the Gammaproteobacteria

472 and belonged to the genus Halomonas. This result underlines the great

473 metabolic versatility of Halomonas species.

475 Strain TH1 originated from Black Sea sediments and had rod-shaped (Fig. 4d),

476 non-motile cells. This strain grew organotrophically on toluene and several

477 organic acids (Table 2) and on the basis of its 16S rRNA gene sequence belongs

478 to a new species within the Alphaproteobacteria.

480 Abundance of hydrocarbon degrading nitrate-reducers in marine 481 sediments

482 Albeit nitrate in marine sediments is much less abundant than sulphate, it plays a 483 key role in the anaerobic mineralization of organic matter, notably in coastal 484 sediments (Jørgensen, 1983). As nitrate concentrations in coastal marine 485 sediments are regulated by a complex range of physico-chemical and micro486 biological factors, they can differ dramatically from one site to another, with 487 denitrification rates reaching up to $1,400 \mathrm{mg} \mathrm{N} \mathrm{m}^{-2}$ day $^{-1}$ (Herbert, 1999). 
489 To estimate the abundance of cultivable toluene or $n$-hexane-degrading 490 denitifiers, most-probable numbers (MPN) were calculated by five replicate

491 anoxic serial dilutions carried out from the original sediments with $5 \mathrm{mM}$ nitrate

492 as electron acceptor. For comparison, MPN series were performed in parallel

493 with benzoate and acetate. Benzoate was chosen as it is a common intermediate

494 in the degradation of alkylbenzenes and polar aromatic compounds in freshwater

495 denitrifying bacteria (Heider \& Fuchs, 1997; Spormann \& Widdel, 2000). Acetate

496 is a key intermediate in the degradation and preservation of organic matter in

497 marine sedimentary habitats. As it is the major fatty acid produced from

498 breakdown of biomass by fermentation, it was expected to allow growth of 499 numerous cultivable denitrifiers. Numbers of cultivable denitrifying prokaryotes 500 utilizing different substrates in sediments from two sites of the sea La Manche 501 were similar, with slightly higher numbers obtained from the oil-polluted harbor 502 samples (LD) (Table 3). MPN counts of hydrocarbon-degrading denitrifiers in 503 sediments from the petroleum-rich ML and NS sediment were substantially 504 higher than for the BS, LD and TB samples (Table 3). The counts for toluene in 505 these petroleum-rich sediments were only two orders of magnitude lower as for 506 acetate $\left(10^{4}\right.$ compared to $10^{6}$ cells $\left./ \mathrm{cm}^{3}\right)$, whereas the difference for the other 507 sediments was three orders of magnitude and more. The results suggest that 508 hydrocarbon-degrading denitrifiers are abundant, especially in coastal petroleum509 rich sediments. 


\section{DISCUSSION}

512 In the present study, we revealed the hitherto unrecognized capability of

513 indigenous prokaryotes from marine sediments to degrade alkylbenzenes and

514 alkanes anaerobically using nitrate as a terminal electron acceptor. Most of these

515 toluene- or $n$-hexane- oxidizing denitrifiers enriched from marine sediments

516 represent new types of hydrocarbon-degraders. The majority of the metabolically

517 active bacteria detected within the enrichment cultures belonged to the Alpha-

518 and Gammaproteobacteria, as well as the Bacteroidetes. Metabolic activity and

519 growth in the enrichments was monitored by substrate consumption, nitrate-

520 reduction, and cell counts. Although the main nitrate-reducing hydrocarbons

521 degraders were identified, not all sequences will belong to organisms directly

522 involved in toluene- or $n$-hexane degradation. A fraction of the bacterial

523 community might have grown with metabolic intermediates derived from the

524 assimilation of toluene or $n$-hexane by primary hydrocarbon-oxidizers. This may,

525 for example, be the case for the enriched Bacteroidetes species, as most

526 Bacteroidetes described so far are chemoorganoheterotrophs involved in the

527 decomposition of organic matter in natural habitats (Bernardet et al., 2002). In

528 brief, we cannot unambiguously conclude from this data alone that all active

529 bacteria identified by molecular methods are bona fide toluene- or $n$-hexane

530 utilizing denitrifiers. However, successful isolation of toluene-oxidizing denitrifiers

531 belonging to the Alpha- and Gammaproteobacteria from four different marine

532 samples confirmed that marine denitrifiers with this metabolic capability are

533 probably widely distributed in these sediments. Although the composition of the 
534 enriched community differed from one habitat to the other, one can conclude that

535 hydrocarbons in marine sediments favour growth of phylogenetically more

536 diverse communities of denitrifiers, than what has been found in freshwater

537 sediments where numerous studies have repeatedly confirmed the dominance of

538 Betaproteobacteria. Surprisingly, even coastal sediments and sediments

539 obtained from petroleum-contaminated harbors, were not dominated by

540 Betaproteobacteria. Furthermore, none of the new microbial isolates was

541 affiliated to the Betaproteobacteria. Why the marine environment favours

542 hydrocarbon-degrading denitrifying microorganisms affiliated to different

543 phylogenetic lineages than those prevailing in freshwater environments can only

544 be speculated about at this time. The hypothesis that Betaproteobacteria able to

545 oxidize hydrocarbons might adapt to the marine environment was not supported

546 by our study. The isolation of new types of toluene-degrading denitrifiers from

547 marine habitats now permits a comparison of pathways involved in anaerobic

548 hydrocarbon degradation among the different groups of denitrifying Alpha-, Beta,

549 and Gammaproteobacteria, and to gain insights into the evolution of these

550 environmentally relevant capacities.

552 Furthermore, the closely related sequences detected in enrichment cultures

553 grown from sediments of different origins, implies that some hydrocarbon-

554 degraders could be widespread within the marine environment. To what extent

555 these denitrifying microorganisms participate in the degradation of hydrocarbons

556 in different marine environments is still unknown. However, nitrate, although less 
557 abundant in the ocean than sulphate, is an energetically favorable electron

558 acceptor and one would expect that it is utilized preferably over sulphate. The

559 use of nitrate and nitrite by the oil industry to prevent souring and control

560 corrosion in oil reservoirs and surface facilities (Gieg et al., 2011; Hubert et al.,

561 2005) could provide conditions favorable for marine denitrifying bacteria.

562 Although detrimental production of sulphite might be reduced by the addition of

563 nitrate, the degradation of hydrocarbons accompanied by the production of large

564 amounts of nitrogen gas would be the consequence.

565

566 Our results confirm that marine sediments are rich in nitrate-reducing

567 microorganisms able to degrade hydrocarbons and that these organisms are

568 clearly different from their freshwater counterparts. The effect these denitrifying

569 hydrocarbon degraders can have on the marine environment, especially on

570 coastal regions where nitrate can be abundant, or on measures to prevent oil

571 souring will be the focus of future studies.

572

573 ACKNOWLEDGEMENTS

574 We thank Christina Probian and Ramona Appel for their help during the first GC

575 and HPLC analyses. We acknowledge Florin Musat for providing samples from a

576 Mediterranean lagoon. This work was supported by the Max-Planck-Society and

577 a grant to K.Z. from the Office of Science (Biological and Environmental

578 Research) for the US Department of Energy (grant DE-SC0004485). 


\section{REFERENCES}

581 Altschul, S. F., Gish, W., Miller, W., Myers, E. W. \& Lipman, D. J. (1990). 582 Basic local alignment search tool. $J$ Mol Biol 215, 403-410.

Alva, V. A. \& Peyton, B. M. (2003). Phenol and catechol biodegradation by the haloalkaliphile Halomonas campisalis: influence of $\mathrm{pH}$ and salinity. Environ Sci Technol 37, 4397-4402.

Amann, R. I., Binder, B. J., Olson, R. J., Chisholm, S. W., Devereux, R. \& Stahl, D. A. (1990). Combination of $16 S$ rRNA-targeted oligonucleotide probes with flow cytometry for analyzing mixed microbial populations. App/ Environ Microbiol 56, 1919-1925.

Austin, B., Calomiris, J. J., Walker, J. D. \& Colwell, R. R. (1977). Numerical taxonomy and ecology of petroleum-degrading bacteria. Appl Environ Microbiol 34, 60-68.

Bernardet, J. F., Nakagawa, Y. \& Holmes, B. (2002). Proposed minimal standards for describing new taxa of the family Flavobacteriaceae and emended description of the family. Int J Syst Evol Microbiol 52, 1049-1070.

Chakraborty, R., O'Connor, S. M., Chan, E. \& Coates, J. D. (2005). Anaerobic degradation of benzene, toluene, ethylbenzene, and xylene compounds by Dechloromonas strain RCB. Appl Environ Microbiol 71, 8649-8655.

Chen, J., Henderson, G., Grimm, C. C., Lloyd, S. W. \& Laine, R. A. (1998). Termites fumigate their nests with naphthalene. Nature 392, 558-559.

Dolfing, J., Zeyer, J., Binder-Eicher, P. \& Schwarzenbach, R. P. (1990). Isolation and characterization of a bacterium that mineralizes toluene in the abscene of molecular oxygen. Archives of Microbiology 154, 336-341.

Ehrenreich, P., Behrends, A., Harder, J. \& Widdel, F. (2000). Anaerobic oxidation of alkanes by newly isolated denitrifying bacteria. Arch Microbiol 173, 58-64.

Evans, P. J., Mang, D. T., Kim, K. S. \& Young, L. Y. (1991). Anaerobic degradation of toluene by a denitrifying bacterium. Applied and Environmental Microbiology 57, 1139-1145.

Felsenstein, J. (1981). Evolutionary trees from DNA sequences: a maximum likelihood approach. J Mol Evol 17, 368-376.

Felsenstein, J. (1985). Confidence limits on phylogenies: an approach using the bootstrap. Evol 30, 783-791. 
625 Fischer-Romero, C., Tindall, B. J. \& Jüttner, F. (1996). Tolumonas auensis 626 gen. nov., sp. nov., a toluene-producing bacterium from anoxic sediments of a 627 freswater lake. Int J Sys Bacteriol 46, 183-188.

Fries, M. R., Zhou, J., Chee-Sanford, J. \& Tiedje, J. M. (1994). Isolation, characterization, and distribution of denitrifying toluene degraders from a variety of habitats. Applied and Environmental Microbiology 60, 2802-2810.

Fuchs, B. M., Zubkov, M. V., Sahm, K., Burkill, P. H. \& Amann, R. (2000). Changes in community composition during dilution cultures of marine bacterioplankton as assessed by flow cytometric and molecular biological techniques. Environ Microbiol 2, 191-201.

Fukui, M., Suwa, Y. \& Urushigawa, Y. (1996). High survival efficiency and ribosomal RNA decaying pattern of Desulfobacter latus, a highly specific acetateutilizing organism, during starvation. FEMS Microbiol Ecol 19, 17-25.

Gauthier, M. J., Lafay, B., Christen, R., Fernandez, L., Acquaviva, M., Bonin, P. \& Bertrand, J.-C. (1992). Marinobacter hydrocarbonoclasticus gen. nov., sp. nov., a new, extremly halotolerant, hydrocarbon-degrading marine bacterium. Int J Sys Bacteriol 42, 568-576.

Gibson, D. T. \& Subramanian, V. (1984). Microbial degradation of aromatic hydrocarbons. In Microbial degradation of aromatic compounds, pp. 181-252. Edited by D. T. Gibson. New York: Marcel Dekker, Inc.

Gieg, L. M., Jack, T. R. \& Foght, J. M. (2011). Biological souring and mitigation in oil reservoirs. Appl Microbiol Biotechnol 92, 263-282.

Gouy, M., Guindon, S. \& Gascuel, O. (2010). SeaView version 4: A multiplatform graphical user interface for sequence alignment and phylogenetic tree building. Mol Biol Evol 27, 221-224.

Heider, J. \& Fuchs, G. (1997). Anaerobic metabolism of aromatic compounds. Eur J Biochem 243, 577-596.

Heider, J., Spormann, A. M., Beller, H. R. \& Widdel, F. (1999). Anaerobic bacterial metabolism of hydrocarbons. FEMS Microbiol Rev 22, 459-473.

Herbert, R. A. (1999). Nitrogen cycling in coastal marine ecosystems. FEMS Microbiol Rev 23, 563-590.

Hess, A., Zarda, B., Hahn, D., Häner, A., Stax, D., Höhener, P. \& Zeyer, J. (1997). In situ analysis of denitrifying toluene- and $m$-xylene-degrading bacteria in a diesel fuel-contaminated laboratory aquifer column. Applied and Environmental Microbiology 63, 2136-2141. 
672 Hubert, C., Nemati, M., Jenneman, G. \& Voordouw, G. (2005). Corrosion risk

673 associated with microbial souring control using nitrate or nitrite. Appl Microbiol

674 Biotechnol 68, 272-282.

675

Huu, N. B., Denner, E. B., Ha, D. T., Wanner, G. \& Stan-Lotter, H. (1999). Marinobacter aquaeolei sp. nov., a halophilic bacterium isolated from a Vietnamese oil-producing well. Int J Syst Bacteriol 49 Pt 2, 367-375.

Jørgensen, B. B. (1983). Processes at the sediment-water interface. In The Major Biogeochemical Cycles and Their Interactions, pp. 477-509. Edited by B. Bolin \& R. B. Cook. New York: J. Wiley \& Sons.

Kemp, P. F., Lee, S. \& Laroche, J. (1993). Estimating the growth rate of slowly growing marine bacteria from RNA content. Appl Environ Microbiol 59, 25942601.

Manz, W., Amann, R., Ludwig, W., Wagner, M. \& Schleifer, K.-H. (1992). Phylogenetic oligodeoxynucleotide probes for the major subclasses of Proteobacteria: problems ans solutions. Syst Appl Microbiol 15, 593-600.

Manz, W., Amann, R., Ludwig, W., Vancanneyt, M. \& Schleifer, K. H. (1996). Application of a suite of $16 \mathrm{~S}$ rRNA-specific oligonucleotide probes designed to investigate bacteria of the phylum Cytophaga-Flavobacter-Bacteroides in the natural environment. Microbiology 142 ( Pt 5), 1097-1106.

Marr, I. L., Cresser, M. S. \& Ottendorfer, L. J. (1988). Umweltanalytik. Eine allgemein Einführung. Stuttgart: Thieme Verlag.

Martinez-Canovas, M. J., Quesada, E., Llamas, I. \& Bejar, V. (2004). Halomonas ventosae sp. nov., a moderately halophilic, denitrifying, exopolysaccharide-producing bacterium. Int J Syst Evol Microbiol 54, 733-737.

Mesbah, M., Premachandran, U. \& Whitman, W. B. (1989). Precise measurement of $\mathrm{G}+\mathrm{C}$ content of deoxyribonuleic acid by high-performance liquid chromatography. Int J Sys Bacterio/ 39, 159-167.

Muyzer, G., Teske, A., Wirsen, C. O. \& Jannasch, H. W. (1995). Phylogenetic relationships of Thiomicrospira species and their identification in deep-sea hydrothermal vent samples by denaturing gradient gel electrophoresis of $16 \mathrm{~S}$ rDNA fragments. Arch Microbiol 164, 165-172.

Narasingarao, P. \& Haggblom, M. M. (2006). Sedimenticola selenatireducens, gen. nov., sp. nov., an anaerobic selenate-respiring bacterium isolated from estuarine sediment. Syst Appl Microbiol 29, 382-388. 
Neef, A. (1997). Anwendung der in situ-Einzelzell-Identifizierung von Bakterien zur Populationsanalyse in Komplexen mikrobiellen Biozönosen. München:

719 Technische Universität, München.

Oelmüller, U., Krüger, N., Steinbüchel, A. \& Friedrich, G. C. (1990). Isolation of prokaryotic RNA and detection of specific mRNA with biotinylated probes. $J$ Microbiol Methods 11, 73-81.

Rabus, R. \& Widdel, F. (1995a). Anaerobic degradation of ethylbenzene and other aromatic hydrocarbons by new denitrifying bacteria. Arch Microbiol 163, 96103.

Rabus, R. \& Widdel, F. (1995b). Anaerobic degradation of ethylbenzene and other aromatic hydrocarbons by new denitrifying bacteria. Archives of Microbiology 163, 96-103.

Rabus, R., Wilkes, H., Schramm, A., Harms, G., Behrends, A., Amann, R. \& Widdel, F. (1999). Anaerobic utilisation of alkylbenzenes and $n$-alkanes from crude oil in an enrichment culture of denitrifying bacteria affiliated with Azoarcus/Thauera cluster. Environ Microbiol 1, 145-157.

Rosselló-Mora, R. \& Amann, R. (2001). The species concept for prokaryotes. FEMS Microbiol Rev 25, 39-67.

Saitou, N. \& Nei, M. (1987). The neighbor-joining method: a new method for reconstructing phylogenetic trees. Molecular Biology and Evolution 4, 406-425.

Sanchez-Porro, C., Kaur, B., Mann, H. \& Ventosa, A. (2010). Halomonas titanicae sp. nov., a halophilic bacterium isolated from the RMS Titanic. Int J Syst Evol Microbiol 60, 2768-2774.

Snaidr, J., Amann, R., Huber, I, Ludwig, W. \& Schleifer, K. -H. (1997). Phylogenetic analysis and in situ identification of bacteria in activated sludge. Appl Environ Microbio/ 63, 2884-2896.

Spormann, A. M. \& Widdel, F. (2000). Metabolism of alkylbenzenes, alkanes, and other hydrocarbons in anaerobic bacteria. Biodegradation 11, 85-105.

Teramoto, M., Suzuki, M., Okazaki, F., Hatmanti, A. \& Harayama, S. (2009). Oceanobacter-related bacteria are important for the degradation of petroleum aliphatic hydrocarbons in the tropical marine environment. Microbiology 155, 3362-3370.

Tissot, B. P. \& Welte, D. H. (1984). Petroleum alteration. In Petroleum formation and occurence, pp. 459-469. New York: Springer-Verlag. 
763 Ventosa, A., Nieto, J. J. \& Oren, A. (1998). Biology of moderately halophilic 764 aerobic bacteria. Microbiol Mol Biol Rev 62, 504-544.

Wallner, G., Amann, R. \& Beisker, W. (1993). Optimizing fluorescent in situ hybridization with rRNA-targeted oligonucleotide probes for flow cytometric identification of microorganisms. Cytometry 14, 136-143.

Weelink, S.A., van Doesburg, W., Saia, F.T., Rijpstra, W.I., Röling, W.F., Smidt, H. \& Stams, A.J. (2009). A strictly anaerobic betaproteobacterium Georgfuchsia toluolica gen. nov., sp. nov. degrades aromatic compounds with $\mathrm{Fe}(\mathrm{III}), \mathrm{Mn}(\mathrm{IV})$ or nitrate as an electron acceptor. FEMS Microbiol Ecol 70, 57585.

Widdel, F. \& Bak, F. (1992). Gram-negative mesophilic sulfate-reducing bacteria. In The Prokaryotes, pp. 3352-3392. Edited by A. Balows, H. G. Trüper, M. Dworkin, W. Harder \& K.-H. Schleifer. Berlin, Heidelberg, New York: SpringerVerlag.

Widdel, F., Boetius, A. \& Rabus, R. (2004). Anaerobic degradation of hydrocarbons including methane. In The Prokaryotes: An Evolving Electronic Resource for the Microbiological Community, pp. http://link.springerny.com/link/service/books/10125/. Edited by M. Dworkin, S. Falkow, E. Rosenberg, K.-H. Schleifer \& E. Stackebrand. New York: Springer.

Widdel, F., Knittel, K. \& Galushko, A. (2010). Anaerobic hydrocarbondegrading microorganisms: an overview. In Handbook of hydrocarbon and lipid microbiology, pp. 1997-2021. Edited by K. N. Timmis. Berlin: Springer.

Zedelius, J., Rabus, R., Grundmann, O., Werner, I., Brodkorb, D., Schreiber, F., Ehrenreich, P., Behrends, A., Wilkes, H., Kube, M., Reinhardt, R. \& Widdel, F. (2011). Alkane degradation under anoxic conditions by a nitratereducing bacterium with possible involvement of the electron acceptor in substrate activation. Environ Microbiol Rep 3, 125-135.

Zengler, K., Richnow, H.H., Rosselló-Mora, R., Michaelis, W. \& Widdel, F. (1999). Methane formation from long-chain alkanes by anaerobic microorganisms. Nature 401, 266.269. 


\section{Figure Legends and Tables}

803 Fig. 1. Nitrate reduction and cell numbers in an enrichment culture from LD

804 sediments on toluene ( $1 \% \mathrm{v} / \mathrm{v}$ in carrier phase) (subculture of the enrichment).

805 Samples for determination of cell numbers in the enrichment culture $(\Delta)$ as well

806 as, nitrate consumption in the enrichment $(\bullet)$ and in substrate-free control $(\circ)$

807 were withdrawn using $\mathrm{N}_{2}$-flushed syringes. Symbol $\downarrow$ : additional nitrate.

809 Fig. 2. Phylogenetic reconstruction showing the affiliations of the 16S rRNA gene

810 sequences of the isolates and clone phylotypes from the $n$-hexane and toluene

811 enrichment cultures performed with TB, ML and LD sediments, and of the

812 toluene-degrading denitrifiers isolated from NS and BS sediments, with selected

813 reference sequences of the Proteobacteria. Sequences from this study are given

814 in bold and the sediments used for these cultures are indicated in brackets. The

815 tree topology shown was obtained by the Neighbour-Joining algorithm, with 1000

816 bootstrap replicates. The scale bar indicates $2 \%$ estimated sequence divergence.

818 Fig. 3. Phylogenetic reconstruction showing the affiliations of the 16S rRNA gene

819 sequences of the clones from the $n$-hexane and toluene enrichment cultures

820 performed with $\mathrm{ML}$ and LD sediments with selected reference sequences of the

821 Bacteroidetes. Sequences from this study are given in bold. The tree topology

822 shown was obtained by the maximum likelihood algorithm, with 100 bootstrap

823 replicates. The scale bar indicates $10 \%$ estimated sequence divergence. 
825 Fig. 4. Phase contrast photomicrographs of novel marine denitrifying bacteria 826 isolated from enrichments cultures with toluene. (a) Strain DT-T originating from 827 muddy sediments from the harbor of Le Dourduff (LD), (La Manche, France), (b) 828 strain TT-Z originating from sandy sediments from Térénez (TB) (La Manche,

829 France), (c) strain Col2 originating from North Sea sediment (NS) and (d) strain

$830 \mathrm{TH} 1$ isolated from Black Sea sediment (BS). Bar, $5 \mu \mathrm{m}$. 
Table 1. Percentages of hybridized cells with group-specific probes relatively to total DAPI cell counts.

\begin{tabular}{lccccc}
\hline Enrichment culture & \multicolumn{5}{c}{ \% of cells hybridized with probe } \\
\cline { 2 - 6 } & EUB338 & ALF968 & BET42a & GAM42a & CF319a \\
\hline Toluene (TB) & 88 & n. d. & n. d. & 80.7 & n. d. \\
Toluene (LD) & 98 & n. d. & 35.7 & 45.9 & 1.4 \\
n-hexane (LD) & 91 & 5.0 & n. d. & 41.8 & 19.8 \\
Toluene (ML) & 82 & n. d. & n. d. & 12.9 & 18.3 \\
n-hexane (ML) & 95 & n. d. & n. d. & 52.6 & 6.0 \\
Toluene (NS) & 93.3 & 1.5 & $>1.0$ & 79.8 & n. d. \\
Toluene (BS) & 91.3 & 73.7 & 5.3 & 3.3 & n. d.
\end{tabular}

n. d. not determined

*oligonucleotide probes (formamide concentration in hybridization buffer):

- $\quad$ EUB338 (35\%): most groups of the domain Bacteria

- ALF968 (20\%): Alphaproteobacteria with the exception of Rickettsiales

- $\quad$ BET42a + GAM42a-competitor (35\%): Betaproteobacteria

- GAM42a + BET42a-competitor (35\%): most groups of Gammaproteobacteria

- $\quad$ CF319a (35\%): some groups of the Cytophaga-Flavobacterium group of the Bacteroidetes

- $\quad$ ARCH915 (35\%): Archaea

- $\quad$ NON338 (10\%): control probe Hybridization with these probes did not exceed $0.1 \%$ of the DAPI stained cells in any enrichment culture. 
Table 2. Physiological characteristics of the toluene-degrading denitrifying isolates.

\begin{tabular}{|c|c|c|c|c|}
\hline Characteristics & Strain DT-T & Strain TT-Z & Strain Col2 & Strain TH1 \\
\hline Phylogenetic affiliation & $\begin{array}{l}\text { Halomonas } \\
\text { sp. }\end{array}$ & $\begin{array}{c}\text { Sedimenticola } \\
\text { sp. }\end{array}$ & $\begin{array}{c}\text { Halomonas } \\
\text { sp. }\end{array}$ & Oceanicola \\
\hline $\begin{array}{l}\text { Temperature range of growth } \\
\left({ }^{\circ} \mathrm{C}\right)\end{array}$ & $4-40$ & $15-30$ & $5-40$ & $15-30$ \\
\hline $\begin{array}{l}\text { Temperature optimum }\left({ }^{\circ} \mathrm{C}\right) \\
\text { DNA G+C content (mol\%) }\end{array}$ & 36 & 28 & $\begin{array}{c}37 \\
68.4\end{array}$ & $\begin{array}{c}28 \\
64.9\end{array}$ \\
\hline \multicolumn{5}{|l|}{$\begin{array}{l}\text { Compounds tested }{ }^{\pi} \text { with } \\
\mathrm{NO}_{3}^{-} \text {as an electron acceptor }\end{array}$} \\
\hline Toluene ( $1 \%$ in HMN) & + & + & + & + \\
\hline Benzene ( $1 \%$ in HMN) & - & - & - & - \\
\hline$o$-xylene ( $1 \%$ in $\mathrm{HMN})$ & - & - & - & - \\
\hline$m$-xylene ( $1 \%$ in $\mathrm{HMN})$ & + & + & - & - \\
\hline$p$-xylene $(1 \% \text { in } \mathrm{HMN})^{\prime}$ & - & - & - & - \\
\hline Ethylbenzene ( $1 \%$ in $\mathrm{HMN})$ & - & - & - & - \\
\hline$n$-hexane $(1 \%$ in HMN) & - & - & n.d. & n.d. \\
\hline$n$-hexadecane ( $1 \%$ in $\mathrm{HMN})$ & - & - & n.d. & n.d. \\
\hline Benzyl alcohol (1 mM) & + & - & + & - \\
\hline Formate $(5 \mathrm{mM})$ & - & + & - & + \\
\hline Acetate $(5 \mathrm{mM})$ & + & + & + & - \\
\hline Propionate $(5 \mathrm{mM})$ & + & + & + & - \\
\hline$n$-butyrate $(5 \mathrm{mM})$ & + & + & + & - \\
\hline Lactate $(5 \mathrm{mM})$ & + & + & + & + \\
\hline Succinate ( $2 \mathrm{mM})$ & + & + & + & + \\
\hline Fumarate $(2 \mathrm{mM})$ & + & + & + & + \\
\hline D/L-malate (2 mM) & + & + & + & + \\
\hline Benzoate $(2 \mathrm{mM})$ & + & + & + & + \\
\hline Phenylacetate (1 mM) & + & + & + & - \\
\hline Yeast extract $(0.5 \%)$ & + & + & n.d. & n.d. \\
\hline Pyruvate $(2 \mathrm{mM})$ & + & + & + & + \\
\hline Glucose (5 mM) & - & - & - & - \\
\hline $\mathrm{H}_{2} / \mathrm{CO}_{2}(80 / 20 \mathrm{v} / \mathrm{v}) 2$ bar & - & - & - & - \\
\hline \multicolumn{5}{|l|}{$\begin{array}{l}\text { Compound tested }{ }^{\star} \text { with } \mathrm{O}_{2} \\
\text { as an electron acceptor }\end{array}$} \\
\hline Toluene $(1 \%)$ in $\mathrm{HMN}$ & - & - & n.d. & n.d. \\
\hline Acetate ( $5 \mathrm{mM}$ ) (agar plates) & + & + & n.d. & n.d. \\
\hline
\end{tabular}

*Each compound was tested twice at the concentration given in brackets, and positive cultures were transferred on the same substrate to confirm growth. Growth was monitored by optical density and confirmed by direct cell counts. Concentrations in percentages (vol/vol) refer to dilutions of hydrophobic compounds in heptamethylnonane (HMN) as an inert carrier phase. Symbols: +, growth; -, no growth; n.d. not determined.

${ }^{\dagger}$ For the experiments carried out under oxic conditions, media were prepared without nitrate. 
Table 3. Most-probable numbers of cultivable bacteria degrading acetate, benzoate, toluene or $n$-hexane with nitrate as a terminal electron acceptor.

\begin{tabular}{llccc}
\hline \multirow{2}{*}{ Sediment } & \multicolumn{4}{c}{ MPN counts $\left(\right.$ cells/cm ${ }^{3}$ ) of denitrifying bacteria with } \\
\cline { 2 - 5 } & acetate & benzoate & toluene & n-hexane \\
\hline Le Dourduff (LD) & $9.2 \times 10^{5}$ & $5.4 \times 10^{4}$ & $5.4 \times 10^{3}$ & $3.5 \times 10^{2}$ \\
Térénez (TB) & $9.2 \times 10^{4}$ & $1.1 \times 10^{3}$ & $3.5 \times 10^{2}$ & $1.7 \times 10^{2}$ \\
Mediterranean & $1.1 \times 10^{6}$ & $2.8 \times 10^{5}$ & $2.2 \times 10^{4}$ & $1.1 \times 10^{4}$ \\
lagoon (ML) & & & & \\
North Sea (NS) & $9.3 \times 10^{5}$ & $1.5 \times 10^{5}$ & $1.1 \times 10^{4}$ & n. d. \\
Black Sea (BS) & $2.2 \times 10^{5}$ & $1.8 \times 10^{3}$ & $6.0 \times 10^{1}$ & n. d. \\
\hline
\end{tabular}

n. d. not determined 


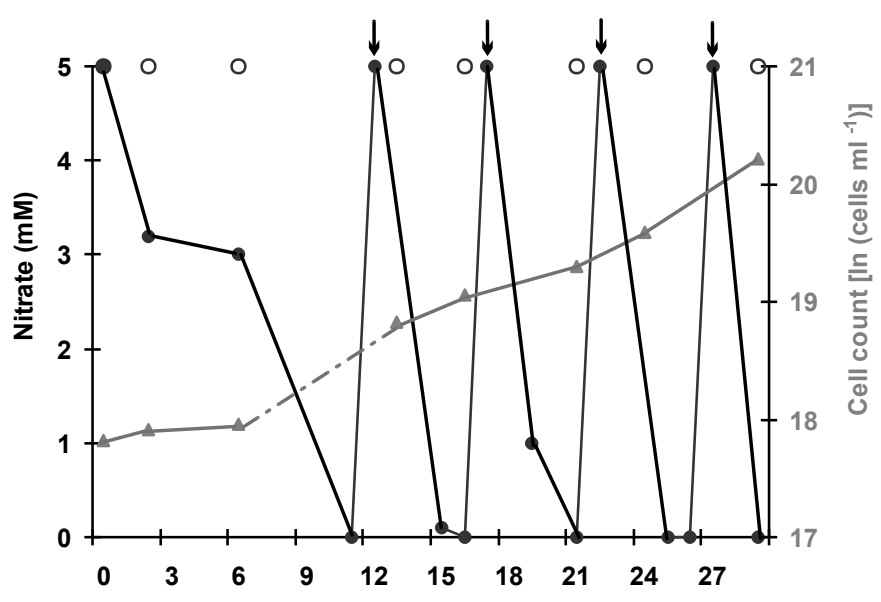

Fig. 1. 


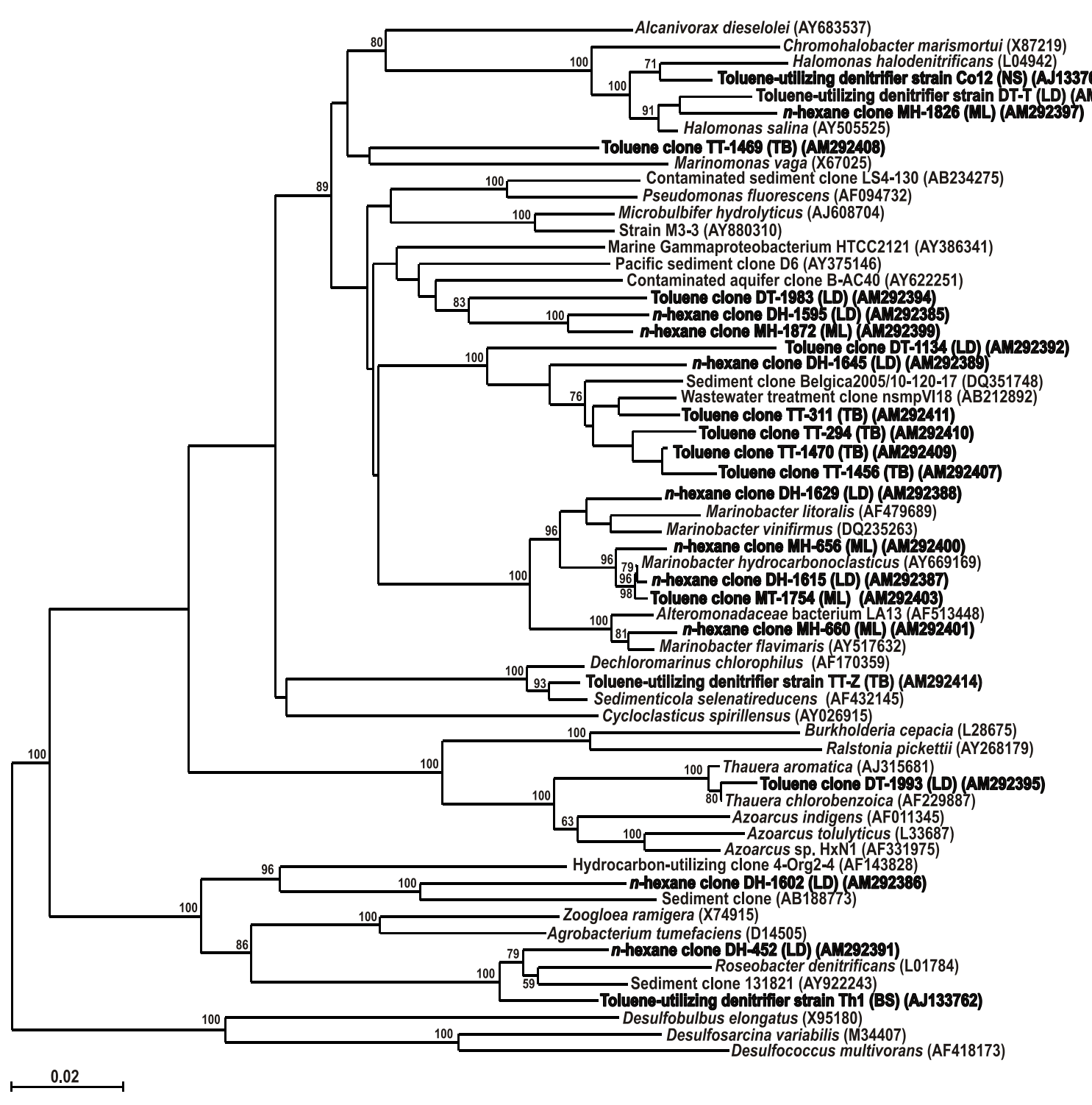

Fig. 2. 


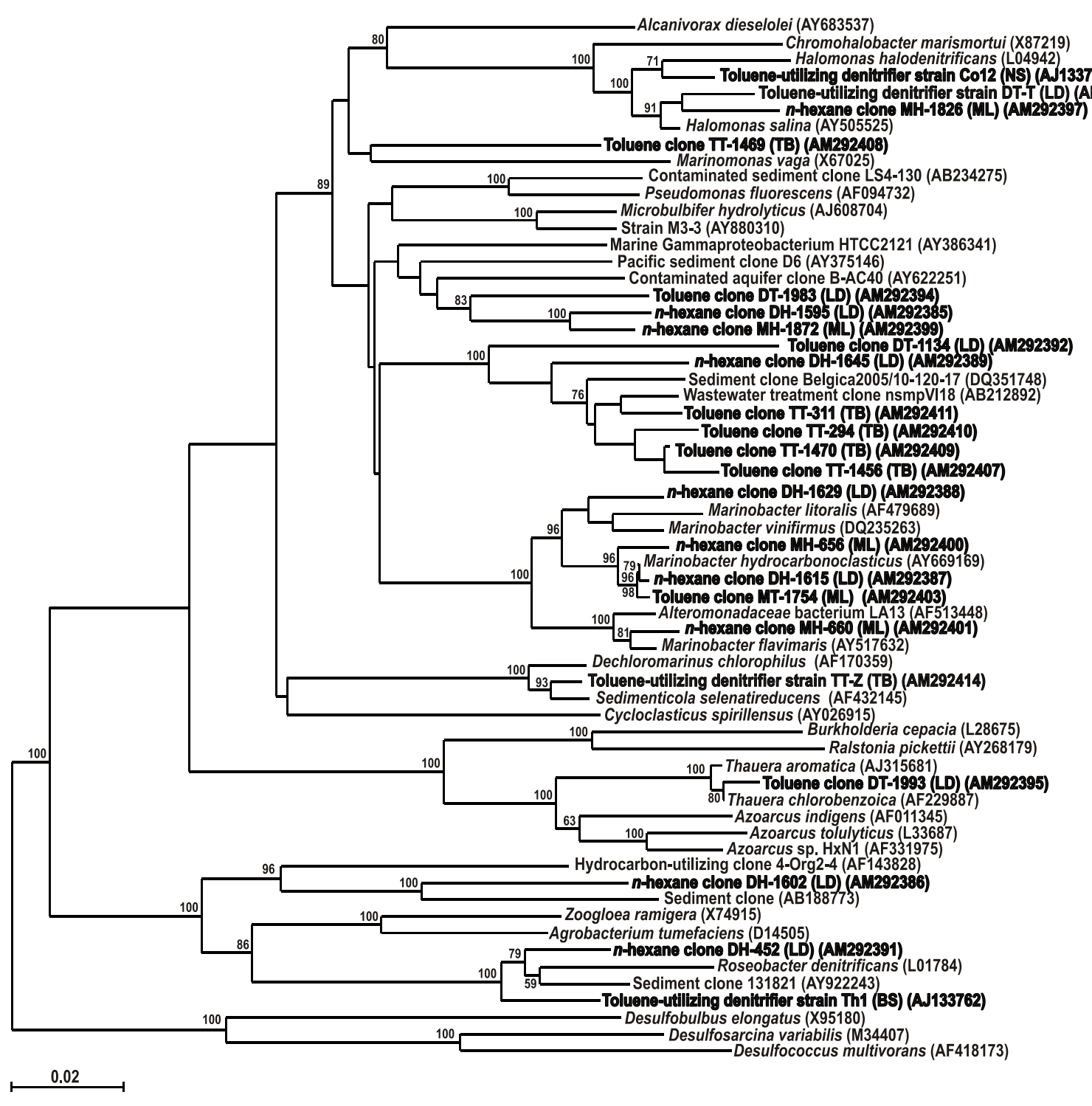

Fig. 3. 


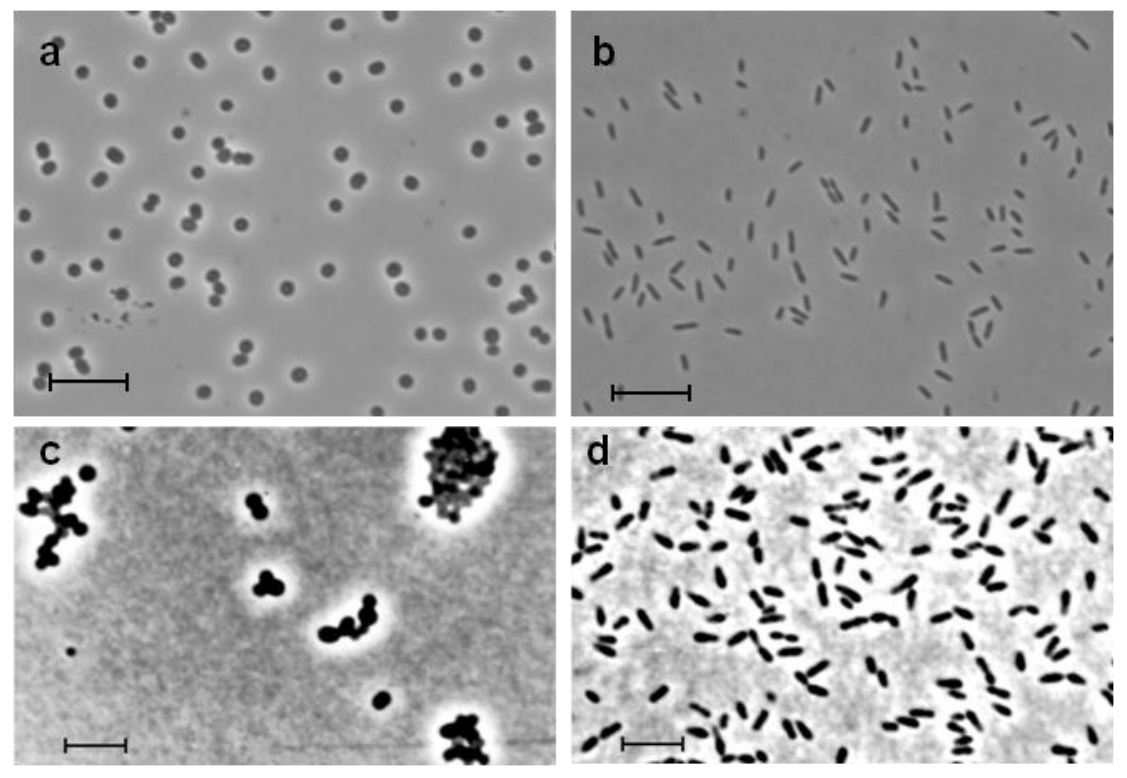

Fig. 4. 